\title{
KEPEMIMPINAN KONTINGENSI ALKITABIAH BAGI PENYELENGARA NEGARA KRISTEN DALAM PELAYANAN PUBLIK
}

\author{
Oleh : \\ ${ }^{* 1}$ Jaka Maryanto dan *2Kezia Yemima \\ ${ }^{1}$ Alumni Sekolah Tinggi Teologi Gamaliel, Surakarta \\ ${ }^{2}$ Dosen Sekolah Tinggi Teologi Gamaliel, Surakarta \\ Email: \\ 1jakamaryanta123@gmail.com, ${ }^{2}$ kezia_y@hotmail.com
}

\begin{abstract}
ABSTRAK - Pelayanan publik di Indonesia memiliki masalah dalam pelaksanaannya karena karakteristik masyarakat yang variatif dan kelemahan pelaksana. Solusi untuk permasalahan ini adalah PNS Kristen harus menerapkan model kepemimpinan alkitabiah. Salah satu model kepemimpinan alkitabiah adalah model kepemimpinan Nehemia. Penelitian ini bertujuan untuk mengaplikasikan model kepemimpinan Nehemia dalam pelayanan publik yang dilakukan oleh PNS Kristen. Penelitian ini menggunakan pendekatan kualitatif dengan metode grounded theory. Penelitian ini menghasilkan model kepemimpinan SMART 2 SMART. Model kepemimpinan SMART 2 SMART merupakan aplikasi model kepemimpinan Nehemia dalam konteks pelayanan publik di Indonesia.
\end{abstract}

Kata Kunci : PNS Kristen, Pelayanan Publik, model kepemimpinan Nehemia

ABSTRACT - Public service in Indonesia had a problem in its implementation because difference need in community and the weakness of the executive. The solution of this problem is christian government employees must apply the biblical leadership model. One of the biblical leadership models is the Nehemiah leadership model. This research aims to apply the Nehemiah leadership model in public service done by christian government employees. This research uses a qualitative approach with the grounded theory method. This research produces the SMART 2 SMART leadership model. SMART 2 SMART leadership model is Nehemiah leadership model that be applied in Indonesia public service context

Keyword : Christian Government Employees, Public Service, Nehemiah Leadership Model 


\section{PENDAHULUAN}

Pelayanan publik merupakan kegiatan untuk memenuhi kebutuhan pelayanan menurut peraturan perundang-undangan bagi setiap warga negara dan penduduk atas barang, jasa, dan pelayanan administratif yang dilakukan oleh penyelenggara pelayanan publik $^{1}$. Pelayanan publik dilakukan oleh penyelenggara Negara (Pegawai Negeri Sipil), korporasi, lembaga independen dan badan hukum lain ${ }^{2}$. Dari definisi diatas, terlihat jelas bahwa penyelenggara Negara (Pegawai Negeri Sipil) harus melakukan pelayanan publik untuk memenuhi kebutuhan masyarakat. Tanpa pelayanan publik, masyarakat tidak akan dapat memenuhi kebutuhannya. Inilah arti penting pelayanan publik.

Permasalahan dalam pelaksanaan pelayanan publik di Indonesia adalah karakteristik masyarakat yang variatif. Kondisi ini membutuhkan pelakuan yang variatif pula dalam pelayanan publik ${ }^{3}$. Permasalahan lain adalah dari penyelenggara pelayanan publik. Penyelenggara pelayanan publik di Indonesia memiliki kelemahan yaitu

\footnotetext{
${ }^{1}$ Presiden Republik Indonesia, Undang-Undang RI No. 25 Tahun 2009 Tentang Pelayanan Publik (Indonesia, 2009), 3, http://pelayanan.jakarta.go.id/download/regulasi /undang-undang-nomor-25-tahun-2009-tentangpelayanan-publik.pdf.

${ }^{2}$ Ibid., 4.

${ }^{3}$ Jumianti Ipah Ema, "Jurnal Adminsitrasi Publik Volume 3 Nomor 1, Juni 2012," Administrasi Publik 3, no. 1 (2012): 36. ${ }^{4}$ Abdul Mahsyar, "Masalah Pelayanan Publik Di Indonesia Dalam Perspektif Administrasi Publik," Otoritas : Jurnal Ilmu Pemerintahan 1, no. 2 (2011): 85.

5 Jaka Maryanto, "Pengaruh Kepemimpinan,

Pembagian Kerja, Dan Motivasi Terhadap
}

kurang responsive, kurang informatif, kurang acceible, kurang koordinasi, bersifat birokratis, kurang mau mendengar keluhan masyarakat dan tidak efisien dalam bekerja ${ }^{4}$.

Jaka Maryanto menyatakan bahwa terdapat pengaruh yang signifikan antara kepemimpinan, pembagian kerja, dan motivasi kerja di Badan Kepegawaian Daerah Kabupaten Karanganyar secara simultan ${ }^{5}$. Semakin baik kepemimpinan, pembagian kerja yang jelas dan motivasi yang tinggi maka semakin baik pula kinerja di kantor BKD Kabupaten Karanganyar. Penelitian yang dilakukan oleh Eni Kristiani Wahyuningsih menunjukkan bahwa kepemimpinan dan Diklat berpengaruh signifikan terhadap motivasi kerja pegawai di Kecamatan Jaten ${ }^{6}$. Penelitian yang dilakukan oleh Arif Rohman menunjukkan bahwa kepemimpinan transformasional berpengaruh positif dan signifikan terhadap komitmen organisasi karyawan Perusahaan Daerah Air Minum (PDAM) Kabupaten Karanganyar ${ }^{7}$. Praptiestrini menyatakan bahwa kedisiplinan merupakan variabel yang dominan dan

Kinerja Pegawai Di Badan Kepegawaian Daerah Kabupaten Karanganyar" (Universitas Slamet Riyadi, 2010), 66-67.

${ }^{6}$ Eni Kristiani Wahyuningsih, "Pengaruh Kepemimpinan, Pendidikan Dan Latihan Terhadap Kinerja Pegawai Dengan Motivasi Sebagai Variabel Intervening" (Sekolah Tinggi Ilmu Ekonomi Adi Unggul Bhirawa, 2010), 73 74.

${ }^{7}$ Arif Rohman, "Pengaruh Kepemimpinan (Transaksional Dan Transformasional) Terhadap Komitmen Organisasi Pada Perusahaan Daerah Air Minum (PDAM) Di Kabupaten Karanganyar" (Universitas Sebelas Maret Surakarta, 2009), 99-100. 
signifikan terhadap motivasi kerja ${ }^{8}$. Penelitian-penelitian diatas menyebutkan bahwa peningkatan kualitas pelaksana pelayanan publik dalam hal cara memimpin dan memanajemen pekerjaan dapat memperbaiki permasalahan pelayanan publik di Indonesia.

Kekristenan meyakini bahwa Alkitab memiliki jawaban bagi berbagai masalah di dunia ini. Alkitab memiliki jawaban yang dapat diterapkan pada era ini. Terkait dengan masalah kepemimpinan dan manajemen, Alkitab memiliki model kepemimpinan Nehemia.

Penelitian

kepemimpinan

Nehemia seperti dilakukan oleh Joko Sembodo menunjukkan bahwa kepemimpinan Nehemia dalam pasal 113 telah memberikan sebuah contoh tentang arti penting sebuah kemampuan manejemen dalam organisasi publik ${ }^{9}$. Sail Lola dan Nelly Petronella Tuhumury menyatakan bahwa kepemimpinan Nehemia patut menjadi pedoman bagi pemimpin-pemimpin masa kini khususnya dalam pelayanan publik ${ }^{10}$. Dalam buku "Nehemia Pemimpin yang Smart dan Komunikatif “, Susan S. Wiradinata juga menyimpulkan bahwa Nehemia mampu menjadi seorang pemimpin yang berhasil karena Nehemia mempunyai karakter yang rendah hati, banyak

\footnotetext{
${ }^{8}$ Praptiestrini, "Pengaruh Kepemimpinan, Lingkungan Kerja, Dan Disiplin Kerja Terhadap Motivasi Kerja Pegawai Dinas Pariwisata Dan Kebudayaan Kabupaten Karanganyar," Jurnal Paradigma 14, no. 1 (2016): 116-117.

9 Joko Sembodo, "Manajemen Sumber Daya Manusia Berdasarkan Nehemia 1-13," Jurnal Antusias 5, no. 1 (2017): 40.
}

berdoa, mau belajar atau berlatih terus menerus.

Orang Kristen memiliki panggilan dalam pelayanan publik salah satunya menjadi Pegawai Negeri Sipil (PNS). Orang Kristen yang menjadi PNS dalam penelitian ini selanjutnya disebut PNS Kristen. Yeremia 29: 7 dan Matius 5: 13-16 mencatat bahwa PNS Kristen harus mensejahterakan kota dengan caranya yang Kristen. Dengan menerapkan model kepemimpinan Nehemia, PNS Kristen dapat memenuhi panggilan ini dan menyelasaikan permasalahan dalam pelayanan publik.

Berdasarkan latar belakang diatas, penulis ingin meneliti kepemimpinan Nehemia dan mengaplikasikannya dalam pelayanan publik. Diharapkan penelitian ini dapat menghasilkan model pelayanan publik baru bagi PNS Kristen yang terlibat dalam pelayanan publik di Indonesia. Peneliti juga berharap orang Kristen dapat dengan mudah menyatakan identitasnya sebagai garam dan terang dunia.

\section{RUMUSAN MASALAH}

Berdasarkan paparan dari permasalahan di atas, rumusan masalah dalam penelitian ini adalah "Bagaimana aplikasi model kepemimpinan Kitab Nehemia dalam konteks pelayanan publik di Indonesia?“. Sedangkan tujuan

\footnotetext{
${ }^{10}$ Sail Lola and Nelly Petronella Tuhumury, "Prinsip-Prinsip Kepemimpinan Transformatif Berdasarkan Kitab Nehemia Dan Implikasinya Bagi Kepemimpinan Rohani Masa Kini," Jurnal Jaffray 8, no. 2 (2010): 67.
} 
dari penelitian ini adalah menemukan model kepemimpinan pelayanan publik berdasarkan model kepemimpinan Kitab Nehemia.

\section{METODE PENELITIAN}

Penelitian dalam artikel ini menggunakan pendekatan kualitatif dengan menggunakan metode grounded theory ${ }^{11}$. Penelitian ini berusaha menyusun teori baru berdasarkan hasil pengabungan dan evaluasi teori yang telah ada. Dalam penelitian ini juga menggunakan metode theologia biblika. Metode theologi biblika berusaha untuk menemukan arti teks Alkitab untuk pembaca pertama dan arti teks tersebut faktual untuk pembaca pada masa kini $^{12}$. Penelitian ini akan mencari arti teks Alkitab dan menerapkannya sebagai model kepemimpinan masa kini. Penelitian ini menggunakan pengumpulan data dengan metode studi pustaka $^{13}$. Adapun data yang dikumpulkan adalah Model Kepemimpinan Nehemia dalam kitab Nehemia, Model Kepemimpinan Kontingensi, Model Kepemimpinan Keterampilan, Model Kepemimpinan Situasional, Model Kepemimpinan Melayani, dan Kepemimpinan PNS di Indonesia.

\footnotetext{
${ }^{11}$ Stevri Indra Lumintang and Danik Astuti Lumintang, Theologia Penelitian Dan Penelitian Theologis (Geneva Insani Indonesia, 2016), 109.

12 Ibid., 124.

${ }^{13}$ J. Lexy Moleong, Metode Penelitian Kualitatif (Bandung: PN Remaja Rosdakarya, 1997), 113.
}

\section{HASIL DAN PEMBAHASAN}

\section{Model Kepemimpinan Nehemia}

Nehemia adalah salah satu tokoh di Alkitab yang melayani sebagai pemimpin di pelayanan publik. Pelayanan publik yang dilakukan oleh Nehemia adalah menjadi bupati Tanah Yehuda. Nehemia menjadi bupati selama 12 tahun (Nehemia 5:14; 13:6-30) ${ }^{14}$. Prestasi yang di kerjakan oleh Nehemia saat menjadi bupati adalah pertama, pembangunan kembali tembok Yerusalem (Nehemia 1-6). Kedua, penyelesaian kasus penindasan antar bangsa Yahudi (Nehemia 5:1-13). Ketiga, pendataan rakyat Yehuda (Nehemia 7:4-73; 11:1-36). Keempat, memfasilitasi kegiatan keagamaan rakyat Yehuda (Nehemia 8-9). Kelima, menegakkan kembali peraturan yang ada serta mengawasi pelaksanaannya (Nehemia 10, 13) ${ }^{15}$. Keenam, Nehemia menghentikan korupsi dalam pelayanan publik (Neh. 13:1-11).

Berikut adalah deskripsi kepemimpinan Nehemia ditinjau dari tiga aspek, pertama, kualitas pribadi, prinsip kepemimpinan, dan keterampilan yang dimiliki.

\section{Kualitas Pribadi Nehemia}

Dampak seorang pemimpin salah satunya ditentukan oleh kualitas pribadinya ${ }^{16}$. Kualitas pribadi Nehemia

\footnotetext{
${ }^{14}$ Andrew E. Hill and John H. Walton, No Title (Malang: Penerbit Gandum Mas, 2004), 377.

${ }^{15}$ Bruce Wilkinson and Kenneth Boa, Talk Thru The Bible (Malang: Penerbit Gandum Mas, 2017), 175-176.

16 Timotius Haryono and Hery Harjanto,

"Model Kepemimpinan Nehemia Dan

Penerapannya Dalam Konteks Pelayanan
} 
adalah pertama, memiliki hubungan pribadi dengan Allah dalam doa ${ }^{17}$. Nehemia berdoa dari bulan Kislew ke bulan Nisan sebelum melakukan pelayanan publik (Neh 1:1-2:1; 2:4). Ketika melakukan pelayanan publik, Nehemia juga senantiasa berdoa (Neh 4:4; 5:19; 6:14; 13:29; 13:31).

Kedua, Nehemia memiliki kepedulian terhadap penduduk Yehuda yang dipimpin. Nehemia sebagai pelayanan publik tidak hanya memperhatikan pembangunan tembok saja. Nehemia berusaha membebaskan bangsa Yahudi dari perbudakan (Neh 5:1-13). Nehemia juga memberikan makanan kepada orang-orang Yahudi, para pemimpin, dan bangsa-bangsa sekeliling (Neh 5:17-18). Oleh karena itu, pelayanan publik Nehemia berdampak luas, tidak hanya membangun tembok saja.

Ketiga, Nehemia menguasai diri sehingga dapat bertindak dengan tepat di berbagai kondisi. Ketika membangun tembok, Nehemia menghadapi berbagai permasalahan diantaranya serangan dari bangsa sekeliling, isu pemberontakkan, dan percobaan pembunuhan. Namun, Nehemia menguasai diri dengan mengingat tugas yang diberikan dan aturan yang berlaku.

Persekutuan Mahasiswa Kristen Masa Kini," Jurnal Penelitian STT Gamaliel 3, no. 1 (2015): 1-19, http://stt-gamaliel.ac.id/index.php/jurnalpenelitian/.

${ }^{17}$ Sail Lola and Petronella Tuhumury, "PrinsipPrinsip Kepemimpinan Transformatif Berdasarkan Kitab Nehemia Dan Implikasinya Bagi Kepemimpinan Rohani Masa Kini," Jurnal Jaffray 8, no. 2 (2010).

${ }^{18}$ Haryono and Harjanto, "Model

Kepemimpinan Nehemia Dan Penerapannya
Keempat, Nehemia merupakan seorang yang terpercaya karena dia jujur, menyelesaikan tugasnya dengan benar dan tepat waktu, berani, taat aturan dan rela berkorban ${ }^{18}$.

\section{Prinsip-prinsip Kepemimpinan Nehemia}

Prinsip-prinsip kepemimpinan berdasarkan kitab Nehemia sebagai berikut: Pertama, berperilaku sesuai dengan rencana Tuhan. Nehemia melayani sebagai pelayan publik diawali dengan doa yang berdasarkan pada Fiman Tuhan (Nehemia 1-2). Rencanarencana yang dikerjakan oleh Nehemia adalah rencana yang dari Tuhan (Nehemia 2:12; 7:5) ${ }^{19}$.

Kedua, memiliki visi dan misi yang jelas 20. Visi Nehemia dalam pelayanan publik diawali dengan membangun kembali tembok Yerusalem. Visi Nehemia spesial karena memenuhi dua area yaitu area fisik (kesejahteraan, keamanan kota melalui pembangunan tembok) dan rohani (nama Tuhan yang dimuliakan). Visi ini juga diturunkan dalam misi yang dikerjakan secara praktis. Misi Nehemia memiliki lokasi dan target yang jelas ${ }^{21}$.

Ketiga, berkomitmen untuk menyelesaikan visi dan misi. Nehemia ketika mengerjakan visi dan misi dalam pelayanan publiknya menghadapi

Dalam Konteks Pelayanan Persekutuan Mahasiswa Kristen Masa Kini."

19 Ibid.

${ }^{20}$ John White, Kepemimpinan Yang Handal

(Bandung: Yayasan Kalam Hidup, 1994), 37.

${ }^{21}$ Haryono and Harjanto, "Model

Kepemimpinan Nehemia Dan Penerapannya

Dalam Konteks Pelayanan Persekutuan Mahasiswa Kristen Masa Kini.” 
banyak tantangan yang berat. Namun tantangan yang berat ini tidak membuat Nehemia berhenti atau berubah, melainkan dia terus mengerjakan serta menyelesaikan pekerjaannya (Nehemia $6: 3)^{22}$.

Keempat, sistem kerja tim yang terkontrol. Nehemia dalam melakukan pelayanan publik tidak sendiriian melainkan bersama tim. Dalam tim tersebut Nehemia membagi tugas dan wewenang kepada timnya. Pembagian kerja Nehemia juga berdasarkan "orang yang tepat di posisi yang tepat". Sehingga tim Nehemia dapat bekerja secara efektif dan efisien. Selain itu Nehemia juga menyeleksi anggota timnya, siapa yang tidak berkomitmen bekerja, tidak diberikan tugas (Nehemia $7: 1-3)^{23}$.

\section{Keterampilan Kepemimpinan Nehemia}

Keberhasilan Nehemia dalam membangun kembali tembok Yerusalem yang roboh tidak lepas dari keterampilan yang dimiliki. Berikut adalah keterampilan yang dimiliki Nehemia. Pertama, Pengetahuan dan ketaatan kepada peraturan. Sebelum Nehemia berangkat untuk melakukan pelayanan publik, dia meminta surat-surat pendukung kepada raja(Nehemia 2:8). Surat-surat tersebut bertujuan agar Nehemia dapat melintasi daerah-daerah dengan lancar dan memperoleh dukungan dalam hal bahan bangunan. Hal ini memperlihatkan Nehemia tahu aturan dan taat kepada aturan.

\footnotetext{
${ }^{22}$ Ibid.

${ }^{23}$ Ibid.

${ }^{24}$ White, Kepemimpinan Yang Handal, 84-85.
}

Kedua, keterampilan observasi sehingga mampu melaksanakan rencana secara tepat dan kontekstual. Keterampilan ini terlihat ketika Nehemia memperoleh rencana dari Allah. Sebelum melaksanakan rencana Allah, Nehemia melakukan observasi lapang. Hasilnya rencana Allah tersebut dilaksanakan oleh Nehemia secara tepat dengan memberdayakan rekan kerja yang ada dengan pembagian tugas yang tepat. Nehemia juga mengamati setiap kondisi tim dan orang-orang yang mencoba menggagalkannya. Hasilnya Nehemia dapat menghadapi perubahan kondisi dan tantangan dengan pengaturan-pengaturan sesuai konteks.

Ketiga, berani menghadapi tantangan. Keberanian Nehemia terlihat dari bagaimana dia menyelesaikan tantangan eksternal. Tantangan eksternal tersebut yaitu adanya ancaman pembunuhan, intimidasi, ancaman perang, dan penghinaan di depan umum. Tantangan ini eksternal ini berasal dari Sanbalat dan Tobia. Mereka berusaha menyelusupkan keputusasaan dan ketakutan $^{24}$. Tujuan akhirnya adalah pembangunan tembok Yerusalem gagal $^{25}$. Kepemimpinan yang baik adalah kepemimpinan yang siap membayar keseluruhan keberadaan pribadinya untuk menyelesaikan tantangan yang ada ${ }^{26}$.

Keempat, memiliki interpersonal skill yang baik untuk berkomunikasi tim kerja (Neh 5:1-13; 7:1-3). Keterampilan ini membuat Nehemia dapat memotivasi

\footnotetext{
${ }^{25}$ Susan W Wiradinata, Nehemia Pemimpin Yang SMART Dan Komunikasi, 2013, 89-90. ${ }^{26}$ Charles W Swindoll, Bekerja Sama Dalam Pembangunan (Surabaya: Yakin, n.d.), 80.
} 
tim kerjanya untuk bekerja sama dengan efektif(Neh. 2:17b-18). Nehemia juga sanggup menguatakan orang yang bekerja dengan dengan setengah hati (termakan provokasi musuh, lelah dan patah semangat) ${ }^{27}$. Nehemia juga mampu menegur tim kerjanya yang melenceng dari tujuan(5:6-7).

\section{Model Kepemimpinan Kontingensi}

Model

Kepemimpinan

Kontingensi adalah model kepemimpinan yang menyesuaikan antara pemimpin dengan situasi yang tepat. Hal ini disebut kontingensi, karena model kepemimpinan ini menyatakan bahwa semakin sesuai gaya pemimpin dengan situasi sekitar maka pemimpin akan semakin efektif sekitar. Fiedler menemukan model kepemimpinan kontingensi dengan mempelajari gaya dari banyak pemimpin yang berbeda yang bekerja di konteks yang berbeda. Intinya, model kepemimpinan kontingensi terkait dengan gaya dan situasi. Model kepemimpinan Kontingensi memberi kerangka kerja untuk menyesuaikan pemimpin dengan situasi secara efektif 28 .

\section{Kualifikasi Pribadi Kepemimpinan}

\section{Kontingensi}

$$
\text { Model kepemimpinan }
$$

Kontingensi membutuhkan pemimpin yang memiliki posisi yang tinggi. Posisi yang dimaksudkan adalah jabatan dalam

\footnotetext{
${ }^{27}$ Wiradinata, Nehemia Pemimpin Yang SMART Dan Komunikasi, 88-89.

${ }^{28}$ Peter G Northouse, Kepemimpinan Teori Dan Praktek (Jakarta: PT Indeks, 2017), 117.

${ }^{29}$ Jerry Lumahlatu, Psikologi Kepemimpinan

(Jakarta: CV. Cipta Varia Sarana, 2011), 46-48.
}

organisasi. Semakin tinggi posisi pemimpin tersebut maka otoritas pemimpin tersebut untuk memberi dampak dan perbuahan di setiap situasi semakin baik ${ }^{29}$.

Model kepemimpinan ini juga membutuhkan integritas yang baik dari pemimpin. Kepemimpinan ini berusaha menyesuaikan kepemimpinan di setiap kondisi 30. Penyesuaian ini membutuhkan relasi yang saling percaya antar pemimpin dan anggota. Tanpa pemimpin yang berintegritas, maka relasi saling percaya tidak akan muncul.

\section{Prinsip Kepemimpinan Kontingensi \\ Model kepemimpinan} Kontingensi memperhatikan pada aspekaspek keterkaitan antara kondisi lingkungan kerja dengan tingkah laku dan kriteria kinerja pemimpin. Model tersebut beranggapan bahwa pemimpin akan mengefektifkan kinerja kelompok bila gaya kepemimpinan (leadership style) sesuai dengan situasi (the favourableness of the situation) yang dihadapinya. Ada tiga faktor utama yang mempengaruhi kesesuaian gaya kepemimpinan dengan situasi ${ }^{31}$. Faktor pertama yaitu hubungan antara pemimpin dan bawahan (leader-member relations). Leader-Member Orientation merupakan hubungan pribadi antara pemimpin dengan para anggotanya. Faktor kedua, struktur tugas (the task structure). Task Structure adalah pengaturan tugas yang diberikan oleh

\footnotetext{
${ }^{30}$ Northouse, Kepemimpinan Teori Dan

Praktek, 43.

${ }^{31}$ F.E Fiedler, A Theory of Leadership Effectiveness (New York: Mc Graw Hill, 1967), 89.
} 
pemimpin untuk dikerjakan oleh anggota. Terakhir, kekuatan posisi (position power). Position Power merupakan tingkat kekuasaan yang diperoleh pemimpin karena kedudukan di organisasi.

\section{Keterampilan Kepemimpinan}

\section{Kontingensi}

\section{Model kepemimpinan}

Kontingensi menuntut tiga keterampilan.

Keterampilan pertama, adalah komunikasi yang baik. Model kepemimpinan ini menekankan relasi yang baik antar pemimpin dan anggota. Model kepemimpemimpinan ini juga mengharapkan pembagian tugas yang jelas dalam tim. Dengan komunikasi yang baik, seorang pemimpin dapat mewujudkannya.

Keterampilan kedua adalah pemahaman visi, misi, tujuan, rencana dan strategi organisasi. Model kepemimpinan kontingensi menghendaki pembagian tugas yang baik dalam tim. Oleh karena itu, pemimpin perlu menguasai visi, misi, tujuan, rencana dan strategi organisasi sehingga dapat memberikan tugas yang tepat untuk mencapai visi organisasi.

Keterampilan ketiga adalah keterampilan untuk beradaptasi. Model kepemimpinan kontingensi akan merubah gaya kepemimpinan sesuai dengan situasi yang ada. Hal ini tentu membutuhkan daya adaptasi yang tinggi. Pemimpin harus bisa menemukan gaya kepemimpinan yang baru di situasi yang baru.

\section{Model Kepemimpinan Keterampilan \\ Model \\ kepemimpinan}

Keterampilan dikemukakan oleh Robert Katz melalui artikel yang berjudul "Skills of an Effective Administrator". Robert Katz menemukan tiga jenis keterampilan yang wajib dimiliki seorang pemimpin ${ }^{32}$. Ketrampilan tersebut adalah keterampilan teknis, manusia, dan konseptual. Ketiga jenis keterampilan ini akan dijelaskan lebih lanjut di bagian keterampilan kepepemimpinan Keterampilan.

\section{Kualifikasi Pribadi Kepemimpinan}

Keterampilan

Model

Kepemimpinan

Keterampilan membutuhkan pemimpin yang memiliki fisik yang dibutuhkan oleh organisasi. Fisik yang dimaksudkan seperti tinggi dan berat badan. Semakin sesuai maka model kepemimpinan ini beranggapan bahwa pemimpin tersebut adalah pemimpin yang efektif.

Penilaian Sosial adalah proses sosial untuk menentukan apakah seseorang 'sukses' atau tidak. Standar penilaian sosial sangat panjang. Panjangnya standar penilaian ini menimbukan pertentangan tentang standar pemimpin yang efektif. Model kepemimpinan Keterampilan memiliki standar yang luas sehingga penentuan kepemimpinan yang efektif terlalu umum/kurang tepat. Model kepemimpinan ini menghubungkan sifat-sifat fisik seperti, tinggi dan berat badan, sebagai penentuan kepemimpinan yang efektif.

\footnotetext{
${ }^{32}$ Robert Katz, "Skills of an Effective Administrator. An HBR Classic.," Harvard Business Review (1974).
} 
Prinsip Kepemimpinan Keterampilan

Model

kepemimpinan

Keterampilan adalah model

kepemimpinan yang menganalisis karakteristik individu pemimpin dari berbagai sisi (keberhasilan dan kegagalannya) dan analasis tersebut digunakan untuk memperkirakan efektivitas kepemimpinan ${ }^{33}$. Anggapan model kepemimpinan ini adalah pemimpin yang sukses memiliki perbedaan baik dari sisi kepribadian maupun fisik dengan para pemimpin kurang efektif.

\section{Keterampilan Kepemimpinan}

\section{Keterampilan}

Menurut Peter G. Northouse hasil dari kepemimpinan keterampilan adalah kinerja yang efektif ${ }^{34}$. Hasil ini sangat dipengaruhi oleh kompetensi pemimpin yaitu keterampilan pemecahan masalah, teknis, manusia dan konseptual. Ketika pemimpin menampilkan kompetensi ini, mereka meningkatkan kemampuan pemecahan masalah dan kinerja mereka secara keseluruhan.

Pemecahan masalah adalah hal utama dalam pendekatan keterampilan. Di dalam model ini, keterampilan pemecahan masalah, seperti kompetensi, menghasilkan pemecahan masalah yang efektif sebagai hasil kepemimpinan. Kriteria untuk pemecahan masalah yang bagus ditentukan oleh keunikan dan kualitas solusi yang diutarakan atas masalah yang ada. Pemecahan masalah yang bagus mencakup penciptaan solusi yang bersifat logis, efektif, dan unik, dan hal itu di luar informasi yang diberikan.

\footnotetext{
${ }^{33}$ Northouse, Kepemimpinan Teori Dan
} Praktek, 43.
Di dalam model kepemimpinan keterampilan, kinerja merefleksikan seberapa baik pemimpin telah melakukan pekerjaannya. Untuk mengukur kinerja, digunakan standar kriteria eksternal. Bila pemimpin telah bekerja dengan baik dan sukses, evaluasi pemimpin akan positif. Pemimpin yang efektif menerima penilaian kinerja tahunan yang bagus, mendapatkan kenaikan gaji, dan diakui oleh atasan dan pengikut sebagai pemimpin yang cakap. Pada akhirnya, kinerja adalah tingkatan di mana pemimpin telah melakukan tugas yang diberikan kepadanya dengan sukses.

Keterampilan pertama adalah keterampilan teknis. Keterampilan kedua adalah keterampilan manusia. Keterampilan terakhir yaitu keterampilan konseptual.

Keterampilan teknis merupakan kemampuan pemimpin untuk melakukan suatu pekerjaan tertentu. Keterampilan ini terkait dengan pengetahuan dan kecakapan seorang pemimpin tentang suatu kegiatan. Misalnya, kemampuan untuk menggunakan komputer untuk kegiatan membuat desain atau pendataan digital.

Keterampilan manusia adalah keterampinan yang memungkinkan seorang pemimpin untuk bekerja dengan orang-orang dalam tim. Ketertampilan manusia berbeda dengan keterampilan teknis yang harus dilakukan dengan bekerja sama dengan peralatan. Kemampuan manusia menentukan pemimpin untuk dapat bergaul, berkomunikasi dan bekerja dalam tim.

\footnotetext{
${ }^{34}$ Ibid., 53.
} 
Keterampilan konseptual adalah kemampuan seorang pemimpin untuk menghasilkan dan mengolah ide-ide dan konsep. Keterampilan ini memungkinkan kita untuk memahami dan lebih baik dalam menentukan tindakan dan langkah-langkah yang harus diambil dalam bidang pekerjaan tertentu.

\section{Model Kepemimpinan Situasional}

Model kepemimpinan situasional adalah model kepemimpinan yang disusun oleh Paul Hersey dalam buku Situational Leader. Model kepemimpinan ini kemudian dikembangkan oleh Ken Blanchard dalam buku Management of Organizational Behavior. ${ }^{35}$

Kepemimpinan situasional mengusahakan gaya kepemimpinan seorang pemimpin untuk berubah-ubah menyesuaikan tingkat kesiapan para pengikutnya. Pemahaman dasar dari model kepemimpinan Situasional adalah tidak ada gaya kepemimpinan yang terbaik. Sedangkan kepemimpinan yang efektif bergantung pada relevansi tugas, dan adaptasi gaya kepemimpinan yang tepat. ${ }^{36}$

Efektivitas kepemimpinan yang dimaksudkan model kepemimpinan Situasional bukan hanya tentang pengaruh kepemimpinan tapi bergantung pula terhadap tugas, pekerjaan atau fungsi yang dibutuhkan secara keseluruhan. Jadi pendekatan kepemimpinan situasional memiliki

\footnotetext{
${ }^{35}$ Ken Blanchard, "A Situational Approach to Managing People," Ignite! Newsletter, no. May (2007): 28-29.

36 Ibid.
}

fokus pada kejadian kepemimpinan di dalam satu peristiwa yang unik.

Dari cara pandang ini, seorang pemimpin menjadi efektif bila mampu menyesuaikan gayanya terhadap berbagai tuntutan situasi yang berubahubah. Model kepemimpinan Situasional menganalisis dua faktor yaitu tingkat kesiapan ayau kematangan pengikut dan gaya kepemimpinan. Selanjutnya, model kepemimpinan situasional menyesuaikan gaya kepemimpinan sesuai dengan tingkat kematangan bawahannya.

\section{Kualifikasi Pribadi Kepemimpinan \\ Situasional}

Kepemimpinan situasional digunakan dalam pemberian konsultasi. ${ }^{37}$ Model kepemipinan ini karena hal itu adalah tujuannya adalah agar anggota tim dapat berperilaku lebih efektif. Oleh karena itu, model ini menghendaki seorang pemimpin yang sudah memiliki anggota.

\section{Prinsip Kepemimpinan Situasional \\ Prinsip Kepemimpinan}

Situasional adalah menyesuaikan gaya kepemimpinan sesuai dengan komitmen dan kompetensi anggota. Blanchard membagi gaya kepemimpinan situsional atas empat gaya ${ }^{38}$. Gaya pertama adalah directing (pengarahan). Pengarahan digunakan untuk bawahan yang berkompetensi rendah tetapi berkomitmen tinggi. Gaya kedua adalah coaching (pelatihan). Gaya pelatihan

\footnotetext{
${ }^{37}$ Ibid.

${ }^{38} \mathrm{KH}$ Blanchard, A Situasional Approach to Managing People (Escondido CA: Blanchard Training and Development, 1985), 51.
} 
digunakan untuk bawahan yang berkompetensi rendah dan berkomitmen rendah. Gaya ketiga adalah supporting (dukungan). Gaya ketiga ini digunakan untuk bawahan yang berkompetensi tinggi tetapi berkomitmen rendah. Gaya keempat yaitu delegating (pendelegasian). Pendelegasian digunakan untuk bawahan yang berkompetensi tinggi dan berkomitmen tinggi.

Hersey and Blanchard mengembangkan 4 gaya kepemimpinan yang bisa dipakai oleh para pemimpin ${ }^{39}$. Gaya kepemimpinan pertama Telling menyuruh. Menyuruh berarti pemimpin menetapkan suatu tugas dan memerintahkan pengikutnya apa, dimana, bagaimana dan kapan melakukan tugas tersebut. Gaya kepemimpinan kedua, Selling - menjual. Gaya kepemimpinan ini berati pemimpin memberikan instruksi terstruktur, tetapi pemimpin hanyaberperilaku supportif. Gaya kepemimpinan ketiga adalah Participating - berpartisipasi. Gaya kepemimpinan berpartisipasi yaitu pemimpin dan para pengikutnya bersama-sama memutuskan bagaimana cara terbaik menyelesaikan suatu pekerjaan. Gaya kepemiminan keempat, Delegating - delegasi. Dalam gaya kepemimpinan ini pemimpin tidak banyak memberikan arahan yang jelas dan spesifik ataupun dukungan pribadi kepada para pengikutnya.

\footnotetext{
${ }^{39}$ P. Hersey and K.H Blanchard, Management
} of Organization Behaviour: Utilizing Human

\section{Keterampilan Kepemimpinan}

Situasional

Model kepemimpinan situasional menekankan pada pengikut dan tingkat kesiapan mereka. Keterampilan yang harus dimiliki para pemimpin dalam kepemimpinan situasional adalah pemimpin harus bisa memperkirakan tingkat kesiapan pengikut mereka. Perkiraan tersebut bertujuan untuk menentukan gaya kepemimpinan yang sesuai dengan tingkat kesiapann tersebut. Kesiapan pengikut terlihat dari dua hal yaitu kemampuan dan kesediaan pengikut untuk mengambil tanggung jawab perilaku mereka. Pengikut dengan kemampuan kerja yang tinggi memiliki pengetahuan dan keahlian sehingga mereka tidak perlu arahan dari manajer untuk melakukan tugas mereka. Seorang yang tingkat kesediaan yang tinggi memiliki dorongan dan keinginan untuk melakukan pekerjaan terbaik demi hasil yang masimal. Pengikut dengan kesiapan tinggi tidak membutuhkan atasan untuk memotivasi bekerja.

Kepemimpinan situasional mengutamakan pada situasi di sekitar pemimpin. Sehingga pemimpin harus menyesuaikan gaya kepemimpinan dengan tuntutan dan berbagai situasi yang berbeda. Model kepemimpinan situasional akan mengatur perintah dan pemberian dukungan dari pemimpin disesuaikan dengan pengikut.

\section{Model Kepemimpinan Melayani}

Model Kepemimpinan Melayani adalah model kepemimpinan yang

Resources (New Jersey: Englewood Clifs Prentice Hall, 1988), 25. 
berawal dari keinginan hati untuk melayani, mengutamakan kebutuhan pengikut, menyelesaikan sesuatu secara bersama dan menolong orang lain untuk mencapai suatu tujuan bersama. Model kepemimpinan Melayani pertama kali dikenalkan oleh Robert K. Greenleaf. Menurut Greenleaf, model kepemimpinan Melayani diawali dengan seseorang yang ingin menjadi pelayan. Seseorang yang ingin memimpin, harus terlebih dulu melayani. Kemudian secara sadar, orang itu membawa orang lain untuk memimpin ${ }^{40}$.

\section{Kualifikasi Pribadi Kepemimpinan \\ Melayani}

Hasil dari Model Kepemimpinan Melayani adalah kualitas pelayanan, jumlah pengikut, kinerja organisasi, dan dampak bagi masyarakat ${ }^{41}$. Oleh karena itu Model Kepemimpinan Melayani membutuhkan pemimpin yang mengutamakan kinerja maksimal bagi pengikut dan masyarakat. Model Kepemimpinan ini mendorong pemimpin bersikap ramah sesuai dengan etika, kebajikan, dan moral yang ada di organisasi dan masyarakat.

\section{Prinsip Kepemimpinan Melayani}

Model Kepemimpinan Melayani mengutamakan kepemimpinan yang memberikan pelayanan terbaik bagi bawahan dan masyarakat atau pelanggannya. Model. Pelaksanaan Model Kepemimpinan Melayani ditentukan oleh kondisi yang berdampak pada kepemimpinan yaitu, pertama, lingkungan masyarakat dan organisasi.

\footnotetext{
${ }^{40}$ Northouse, Kepemimpinan Teori Dan Praktek, 99.
}

Model Kepemimpinan Melayani hendak mempengaruhi masyarakat dan organisasi. Lingkungan mayarakat dan organisasi akan menentukan gaya kepemimpinan yang paling tepat. Kedua, karakter pemimpin. Karakter pemimpin akan mengarahkan pemimpin kepada suatu gaya kepemimpinan yang berbeda untuk setiap kondisi. Ketiga, kemampuan pengikut. Kemampuan pengikut akan menentukan gaya kepemimpinan dan cepat atau lambatnya pengaruh seorang pemimpin.

\section{Keterampilan Kepemimpinan Melayani}

Keterampilan yang dibutuhkan dalam Model Kepemimpinan Melayani, yaitu sebagai berikut: Pertama, Mendengarkan. Model Kepemimpinan Melayani mendengarkan orang lain, organisasi dan dirinya sendiri untuk mencari kebutuhan dan strategi yang tepat untuk menjawabnya. Kedua, Empati. Model Kepemimpinan Melayani berusaha merasakan secara mendalam apa yang dihadapi rekan kerja maupun orang lain. Ketiga, Penyembuhan. Model Kepemimpinan Melayani mampu menciptakan penyembuhan emosi dan relasi dalam organisasi dan masyarakat. Keempat, Kesadaran. Model Kepemimpinan Melayani membutuhkan kesadaran untuk memahami isu-isu yang melibatkan etika, kekuasaan, dan nilainilai. Kelima, Persuasi. Model Kepemimpinan Melayani mengutamakan metode meyakinkan daripada memaksa agar orang lain patuh. Keenam, Konseptualisasi. Model

\footnotetext{
${ }^{41}$ Ibid., 235.
} 
Kepemimpinan Melayani membutuhkan kemampuan melihat masalah secara jangka panjang dalam basis yang lebih luas. Ketujuh, Kejelian. Model Kepemimpinan Melayani membutuhkan kejelian untuk memahami pelajaran dari masa lalu, kondisi masa kini, dan ancaman serta resiko di masa depan. Kedelapan, Keterbukaan. Model Kepemimpinan Melayani mengutamakan keterbukaan untuk membangun komunikasi dan relasi dengan orang lain. Kesembilan, Komitmen untuk Pertumbuhan. Model Kepemimpinan Melayani menuntut tanggung jawab untuk melakukan setiap kegiatan sehingga dapat meningkatkan pertumbuhan profesional karyawan dan organisasi. Kesepuluh, Membangun Komunitas. Model Kepemimpinan Melayani mengidentifikasi metode yang tepat untuk membangun komunitas ${ }^{42}$.

\section{Kepemimpinan PNS di Indonesia}

Pegawai Negeri Sipil (PNS) merupakan warga negara Indonesia yang memenuhi syarat tertentu, diangkat sebagai pegawai Aparatur Sipil Negara (ASN) secara tetap oleh pejabat pembina kepegawaian untuk menduduki jabatan tertentu ${ }^{43}$. PNS merupakan satu profesi yang diberikan oleh pemerintah (Indonesia). Berikut adalah saran kepemimpinan PNS dalam undangundang

\footnotetext{
${ }^{42}$ RK Greenleaft, Servant Leadership: A Jouney into the Nature of Legitimate Power and Greatness (New York: Paulist Press, 1977), 41.

${ }^{43}$ Dewan Perwakilan Rakyat and Presiden Republik Indonesia, Undang-Undang Nomor 5 Republik Indonesia Tentang Aparatur Sipil Negara Tahun 2014 (Indonesia, 2014), 3,
}

Kualifikasi Pribadi Kepemimpinan PNS

Secara umum kepemimpinan atau manajemen PNS di Indonesia telah diatur dalam Peraturan Pemerintah Nomor 11 Tahun 2017 tentang Manajemen Pegawai Negeri Sipil. Tujuan kepemimpinan atau manajemen pegawai negeri sipil adalah pengelolaan pegawai negeri sipil untuk menghasilkan pegawai negeri sipil yang profesional, memiliki nilai dasar, etika profesi, bebas dari intervensi politik, bersih dari praktik korupsi, kolusi, dan nepotisme ${ }^{44}$. Dari tujuan tersebut tercermin kualifikasi pribadi kepemimpinan PNS secara umum.

\section{Prinsip Kepemimpinan PNS}

Prinsip utama kepemimpinan PNS dalam PP 11 Tahun 2017 adalah melayani kepentingan publik secara profesional. PNS mempunyai tugas utama melayani kepentingan publik atau rakyat, dan bertugas memberikan pelayanan kepada masyarakat secara profesional, jujur, adil dan merata dalam penyelenggaraan tugas negara, pemerintah dan pembangunan 45 .

\section{Keterampilan Kepemimpina PNS}

Keterampilan Kepemimpinan PNS dibutuhkan untuk menghasilkan pelayanan publi yang susuai dengan standar. Ada empat standar yang harus di wujudkan oleh PNS. Standar pertama, penyelenggara harus menyusun dan

sc.syekhnurjati.ac.id/esscamp/aturan/APARAT

UR_SIPIL_NEGARA_(ASN).pdf $\% 5 \mathrm{Cn}$.

${ }^{44}$ Presiden Republik Indonesia, Peraturan

Pemerintah Republik Indonesia Nomor 11

Tahun 2017 Tentang Manajemen Pegawai Negeri Sipil Dengan (Indonesia, 2017).

${ }^{45}$ Ibid. 
menetapkan standar pelayanan dengan memperhatikan kemampuan penyelenggara, kebutuhan masyarakat, dan kondisi lingkungan. Standar kedua, dalam menyusun dan menetapkan standar pelayanan, penyelenggara wajib mengikutsertakan masyarakat dan pihak terkait. Dari standar ini PNS harus memiliki keterampilan interpersonal yang baik. Dengan keterampilan interpersonal yang baik maka PNS dapat mengikutsertakan tidak hanya masyarakat tetapi juga anggota tim. Ketiga, penyelenggara berkewajiban menerapkan standar pelayanan dengan prinsip tidak diskriminatif, terkait langsung dengan jenis pelayanan, memiliki kompetensi dan mengutamakan musyawarah, serta memperhatikan keberagaman. Keempat, Penyusunan standar pelayanan dilakukan dengan pedoman tertentu yang diatur lebih lanjut dalam peraturan pemerintah.

\section{Analisis Data}

Kualifikasi pribadi kepemimpinan Nehemia yaitu memiliki hubungan pribadi dengan Allah dalam doa, memiliki kepedulian terhadap penduduk Yehuda yang dipimpin, menguasai diri dalam berbagai kondisi, dan terpercaya. Kualifikasi pribadi kepemimpinan Kontingensi yaitu memiliki posisi yang tinggi dan membutuhkan integritas yang baik dari pemimpin. Kualifikasi pribadi dari kepemimpinan keterampilan adalah memiliki fisik yang dibutuhkan oleh organisasi. Kualifikasi pribadi kepemimpinan situasional adalah seorang pemimpin yang sudah memiliki anggota. Kualifikasi pribadi kepemimpinan melayani adalah orang yang berkeinginan untuk memberi pelayanan terbaik bagi bawahan dan pelanggannya dan senantiasa mendorong dirinya untuk ramah dengan siapapun, menjaga etika, kebajikan, dan moral. Sedangkan kualifikasi pribadi kepemimpinan PNS yaitu profesional, memiliki nilai dasar, etika profesi, bebas dari intervensi politik, bersih dari praktik korupsi, kolusi, dan nepotisme. Oleh karena itu, kualifikasi pribadi pada model yang baru akan menghendaki pemimpin memiliki hubungan pribadi dengan Allah dalam doa, peduli dengan rakyat Indonesia, dan menguasai diri yang diwujudkan dengna sikap ramah kepada semua orang, berintegritas dan terpercaya karena memiliki etika profesional, menyelesaikan tugas dengan benar dan tepat waktu, taat aturan, rela berkorban, bebas intervensi politik, bebas dan berani melawan $\mathrm{KKN}$, serta memiliki fisik yang dibutuhkan organisasi.

Prinsip kepemimpinan Nehemia adalah berperilaku sesuai dengan rencana Tuhan, memiliki visi dan misi yang jelas, berkomitmen untuk menyelesaikan visi dan misi, dan memiliki sistem kerja yang terkontrol. Prinsip kepemimpinan kontingensi adalah kesesuaian antara hubungan pemimpin dan bawahan, struktur tugas serta tingkat kekuasaan yang diperoleh pemimpin organisasi karena kedudukan. Prinsip kepemimpinan Keterampilan adalah menganalisis karakteristik individu pemimpin secara multidimensional, baik keberhasilan dan kegagalannya untuk memprediksi 
efektifitas kepemimpinan. Prinsip kepemimpinan Situasional adalah menyesuaikan gaya kepemimpinan sesuai dengan komitmen dan kompetensi anggota. Kepemimpinan Melayani memiliki prinsip melakukan pelayanan yang terbaik bagi bawahan dan pelanggannya serta mendorong dirinya untuk bersikap ramah dengan siapapun, menjaga etika, kebajikan dan moral. Sedangkan kepemimpinan PNS memiliki prinsip melayani kepentingan publik secara profesional. Oleh karena itu, model kepemimpinan yang baru akan memiliki prinsip yaitu memiliki visi dan misi yang dari Allah untuk melayani kepentingan publik secara profesional dan mengajak PNS lain dan pihak-pihak terkait untuk melakukan hal yang sama.

Keterampilan yang dibutuhkan dalam kepemimpinan Nehemia adalah pengetahuan dan ketaatan kepada peraturan, keterampilan observasi sehingga mampu melaksanakan rencana secara tepat dan kontekstual, berani menghadapi tantangan, serta memiliki interpersonal skill yang baik untuk berkomunikasi dengan tim kerja. Kepemimpinan Kontingensi menghendaki pemimpin memiliki keterampilan komunikasi yang baik, pemahaman visi, misi, tujuan, rencana dan strategi organisasi, serta kemampuan untuk beradaptasi di berbagai kondisi. Kepemimpinan Keterampilan menghendaki pemimpin memiliki kemampuan memecahkan masalah, teknis, manusia dan konseptual. Kepemimpinan Situasional membutuhkan keterampilam menilai dengan tepat atau secara intuitif tingkat kematangan pengikut. Keterampilan yang dibutuhan oleh kepemimpinan melayani yaitu mendengar dan memahami kelompok dan orang lain, dapat memulihkan emosi dan relasi, dapat memahami isu yang melibatkan etika, kekuasaan, dan nilai-nilai, dapat meyakinkan orang lain untuk patuh, dapat melihat masalah secara jangka panjang, jeli dan teliti dalam memahami pelajaran dari masa lalu, menekankan keterbukaan dan persuasi untuk membangun kepercayaan orang lain, bertanggungjawab untuk melakukan usaha dalam meningkatkan pertumbuhan profesional karyawan dan organisasi, dan mengidentifikasi cara untuk membangun komunitas. Keterampilan yang dibutuhkan dalan kepemimpinan PNS adalah mampu menyusun dan menetapkan standar pelayanan dengan memperhatikan kemampuan penyelenggara, kebutuhan masyarakat dan kondisi lingkungan, memiliki interpersonal skill yang baik untuk mengikutsertakan masyarakat dan pihak terkait, menerapkan standar pelayanan dengan prinsip tidak diskriminatif, terkait langsung dengan jenis pelayanan, memiliki kompetensi dan mengutamakan musyawarah, serta memperhatikan keberagaman, serta memiliki keterampilan untuk mengetahui pedoman peraturan pemerintah. Oeh karena itu, model kepemimpinan baru nanti akan membutuhkan keterampilan pengetahuan dan ketaatan aturan pemerintah Republik Indonesia, dapat menyusun rencana yang berdasarkan kebutuhan masyarakat dan kondisi lingkungan dimana ditempatkan, serta 
sesuai dengan standar undang-undang, interpersonal skill dan komunikasi yang baik dengan tim kerja dan masyarkat, dan memiliki kemampuan adaptasi yang baik sehingga dapat bekerja sama dengan pihak terkait dan masyarakat.

Hasil sintesis data penelitian adalah model Kepemimpinan yang baru yang dapat diterapkan di pelayanan publik. Peneliti memberi memberi nama model kepemimpnan "SMART 2 SMART". SMART 2 SMART merupakan singkatan dari tiga komponen model kepemimpinan ini. Berikut adalah penjelasannya.

Kata SMART pertama merupakan akronim dari lima kualifikasi pribadi model kepemimpinan SMART 2 SMART. Kualifikasi pribadi pertama yaitu Sehat yang berarti seorang PNS Kristen harus sehat jasmani dan rohani untuk melaksanakan tugas yang dibebankan. Kedua, Menguasai diri. Menguasai diri berarti PNS Kristen harus mengontrol perilaku sehingga dapat bersikap ramah kepada semua orang baik dalam pelayanan publik maupun dalam kehidupan sehari-hari. Ketiga, Acuh. Acuh merupakan sinonim dari kata peduli. PNS Kristen harus memiliki hati peduli terhadap rakyat Indonesia. Keempat, Relasi dengan Allah. PNS Kristen harus memiliki relasi dengan Allah yang diwujudkan dalam bentuk suka berdoa dan beribadah. Kelima, Terpercaya dan berintegritas. PNS Kristen harus memiliki etika profesional, menyelesaikan tugas dengan benar dan tepat waktu, taat aturan, rela berkorban, bebas intervensi politik, bebas dan berani melawan KKN.
Dengan demikian PNS Kristen akan terpercaya dan berintegritas.

Angka 2 (dua) dalam model SMART 2 SMART merupakan prinsip yang ada dalam model kepemimpinan ini. Model kepemimpinan SMART 2 SMART memiliki 2 prinsip yaitu pertama, memiliki visi dan misi dari Allah untuk melayani kepentingan publik secara profesional. Model kepemimpinan ini menghendaki PNS Kristen mengerjakan rencana Allah bagi Indonesia melalui pelayanan publik yang profesional. Prinsip kedua adalah mengajak PNS lain dan pihak-pihak terkait untuk melakukan kepemimpinan SMART 2 SMART. PNS Kristen dalam pelayanan publik akan bertemu dan bekerjasama dengan banyak orang (PNS lain maupun masyarakat). Ketika pertemuan dan kerjasama ini terjadi maka PNS Kristen harus dapar mendorong, mempersuasi, dan mempengaruhi orang lain untuk meniru sebagian maupun seluruh model kepemimpinan SMART 2 SMART.

Kata SMART kedua dalam model SMART 2 SMART merupakan akronim dari lima keterampinan yang diharapkan dikuasai seorang PNS Kristen. Keterampilan pertama adalah Santun. PNS Kristen harus menguasai kemampuan interpersonal dan komunikasi. Sehingga PNS Kristen dapat berperilaku santun dalam bekerja sama dengan banyak orang. Keterampilan kedua yaitu Mengetahui peraturan dan udang-undang di pemerintah republik Indonesia. Adaptasi adalah keterampilan ketiga. PNS Kristen harus dapat beradaptasi dengan keberagaman (suku, agama, ras, dan 
golongan) di Indonesia. Sehingga PNS

Kristen tidak hanya dapat bekerjasama tetapi juga mempengaruhi banyak orang di Indonesia. Keempat, Rencana. PNS Kristen harus dapat menyusun rencana pelayanan publik yang berdasarkan kebutuhan masyarakat, kondisi lingkungan dan sesuai dengan standar undang-undang. Keterampilan terakhir adalah Taat. Taat yang dimaksudkan adalah dalam melaksanakan pelayanan publik PNS Kristen harus taat aturan yang berlaku di Indonesia.

\section{KESIMPULAN}

Kesimpulan dari penelitian ini adalah aplikasi model kepemimpinan Nehemia dalam pelayanan publik dapat dilakukan dengan menerapkan model kepemimpinan SMART 2 SMART. Model kepemimpinan SMART 2 SMART membutuhkan pemimpin dengan kualifikasi pribadi sehat, menguasai diri, acuh, relasi dengan Allah, terpercaya dan berintegritas. Model kepemimpinan ini berprinsip memiliki visi dan misi dari Allah untuk melayani kepentingan publik secara profesional dan mengajak PNS lain dan pihak-pihak terkait untuk melakukan kepemimpinan SMART 2 SMART. Keterampilan yang diharapkan dikuasai dalam model kepemimpinan ini adalah santun, mengetahui peraturan dan udang-undang, adaptasi, rencana, taat.

Peneliti, melalui penelitian ini memberikan saran yaitu pertama, bagi PNS Kristen yang ada di pelayanan publik. PNS Kristen yang memimpin di pelayanan publik hendaknya menerapkan model kepemimpinan alkitabiah. Dengan menerapkan Model kepemimpinan SMART 2 SMART, pemimpin Kristen sudah menerapkan kepemimpinan yang alkitabiah. Dengan menerapkan SMART 2 SMART, pemimpin Kristen dapat menyatakan identitasnya yaitu terang dan garam dunia.

Saran kedua, bagi peneliti dan cedekiawan Kristen lain. Model kepemimpinan SMART 2 SMART memiliki potensi untuk diterapkan di konteks lain. Oleh karena itu melalui penelitian ini, peneliti menyarankan untuk cendekiawan Kristen untuk meneliti aplikasi model SMART 2 SMART dikonteks lain.

\section{REFERENSI}

Blanchard, Ken. "A Situational Approach to Managing People." Ignite! Newsletter, no. May (2007): 28-29.

Blanchard, KH. A Situasional Approach to Managing People. Escondido

CA: Blanchard Training and Development, 1985.

Dewan Perwakilan Rakyat, and Presiden Republik Indonesia. Undang-Undang Nomor 5 Republik Indonesia Tentang Aparatur Sipil Negara Tahun 2014. Indonesia, 2014. sc.syekhnurjati.ac.id/esscamp/atura n/APARATUR_SIPIL_NEGARA_ (ASN).pdf\%5Cn.

Ema, Jumianti Ipah. "Jurnal Adminsitrasi Publik Volume 3

Nomor 1, Juni 2012." Administrasi

Publik 3, no. 1 (2012): 25-31.

Fiedler, F.E. A Theory of Leadership Effectiveness. New York: Mc Graw Hill, 1967. 
Greenleaft, RK. Servant Leadership: A Jouney into the Nature of

Legitimate Power and Greatness. New York: Paulist Press, 1977.

Haryono, Timotius, and Hery Harjanto.

"Model Kepemimpinan Nehemia

Dan Penerapannya Dalam Konteks

Pelayanan Persekutuan Mahasiswa

Kristen Masa Kini.” Jurnal

Penelitian STT Gamaliel 3, no. 1

(2015): 1-19. http://stt-

gamaliel.ac.id/index.php/jurnal-

penelitian/.

Hersey, P., and K.H Blanchard.

Management of Organization

Behaviour: Utilizing Human

Resources. New Jersey:

Englewood Clifs Prentice Hall, 1988.

Hill, Andrew E., and John H. Walton.

No Title. Malang: Penerbit

Gandum Mas, 2004.

Katz, Robert. "Skills of an Effective

Administrator. An HBR Classic."

Harvard Business Review (1974).

Lola, Sail, and Nelly Petronella

Tuhumury. "Prinsip-Prinsip

Kepemimpinan Transformatif

Berdasarkan Kitab Nehemia Dan

Implikasinya Bagi Kepemimpinan

Rohani Masa Kini." Jurnal Jaffray

8 , no. 2 (2010).

Lola, Sail, and Petronella Tuhumury.

"Prinsip-Prinsip Kepemimpinan

Transformatif Berdasarkan Kitab

Nehemia Dan Implikasinya Bagi

Kepemimpinan Rohani Masa

Kini." Jurnal Jaffray 8, no. 2

(2010).

Lumahlatu, Jerry. Psikologi

Kepemimpinan. Jakarta: CV. Cipta

Varia Sarana, 2011.
Lumintang, Stevri Indra, and Danik

Astuti Lumintang. Theologia

Penelitian Dan Penelitian

Theologis. Geneva Insani

Indonesia, 2016.

Mahsyar, Abdul. "Masalah Pelayanan

Publik Di Indonesia Dalam

Perspektif Administrasi Publik."

Otoritas : Jurnal Ilmu

Pemerintahan 1, no. 2 (2011): 8190.

Maryanto, Jaka. "Pengaruh

Kepemimpinan, Pembagian Kerja,

Dan Motivasi Terhadap Kinerja

Pegawai Di Badan Kepegawaian

Daerah Kabupaten Karanganyar."

Universitas Slamet Riyadi, 2010.

Moleong, J. Lexy. Metode Penelitian

Kualitatif. Bandung: PN Remaja

Rosdakarya, 1997.

Northouse, Peter G. Kepemimpinan

Teori Dan Praktek. Jakarta: PT

Indeks, 2017.

Praptiestrini. "Pengaruh

Kepemimpinan, Lingkungan Kerja,

Dan Disiplin Kerja Terhadap

Motivasi Kerja Pegawai Dinas

Pariwisata Dan Kebudayaan

Kabupaten Karanganyar." Jurnal

Paradigma 14, no. 1 (2016).

Presiden Republik Indonesia. Peraturan

Pemerintah Republik Indonesia

Nomor 11 Tahun 2017 Tentang

Manajemen Pegawai Negeri Sipil

Dengan. Indonesia, 2017.

- Undang-Undang RI No. 25

Tahun 2009 Tentang Pelayanan

Publik. Indonesia, 2009.

http://pelayanan.jakarta.go.id/down

load/regulasi/undang-undang-

nomor-25-tahun-2009-tentang-

pelayanan-publik.pdf. 
Rohman, Arif. "Pengaruh

Kepemimpinan (Transaksional

Dan Transformasional) Terhadap

Komitmen Organisasi Pada

Perusahaan Daerah Air Minum

(PDAM) Di Kabupaten

Karanganyar." Universitas Sebelas

Maret Surakarta, 2009.

Sembodo, Joko. "Manajemen Sumber

Daya Manusia Berdasarkan

Nehemia 1-13." Jurnal Antusias 5, no. 1 (2017).

Swindoll, Charles W. Bekerja Sama

Dalam Pembangunan. Surabaya:

Yakin, n.d.

Wahyuningsih, Eni Kristiani. "Pengaruh

Kepemimpinan, Pendidikan Dan

Latihan Terhadap Kinerja Pegawai

Dengan Motivasi Sebagai Variabel

Intervening." Sekolah Tinggi Ilmu

Ekonomi Adi Unggul Bhirawa,

2010.

White, John. Kepemimpinan Yang

Handal. Bandung: Yayasan Kalam

Hidup, 1994.

Wilkinson, Bruce, and Kenneth Boa.

Talk Thru The Bible. Malang:

Penerbit Gandum Mas, 2017.

Wiradinata, Susan W. Nehemia

Pemimpin Yang SMART Dan

Komunikasi, 2013. 